\title{
Effect of Cadmium Pretreatment on Teratogenicity and Fetolethality of Cadmium
}

\author{
By

\begin{abstract}
Reiji Semba, Hideki Yamamura* and Ujihiro Murakami
\end{abstract} \\ Institute for Developmental Research, Aichi Prefectural \\ Colony, Kasugai, Aichi 480-03, Japan.
}

-Received for Publication, June 24, 1977-

\section{Introduction}

Through various experiments on toxicity, teratogenicity and fetolethality of cadmium, it was found that these actions of cadmium are influenced by simultaneous administration of some other metals. For example, zinc blocks almost completely the toxicity (Parizek, 1957), teratogenicity and fetolethality (Ferm and Carpenter, 1968) of cadmium. On the other hand, it was reported that pretreatment with cadmium protects, to some extent, the animals from acute toxicity of subsequent administration of a higher dose of cadmium itself (Ito and Sawauchi, 1966., Yoshikawa, 1970). However, since it is still unclear as to whether or not teratogenicity and/or fetolethality of cadmium are reduced by preadministration of a lower dose of cadmium, the present experiment is designed to investigate this question. Yamamura (1972) reported that when $5 \mathrm{mg} / \mathrm{kg}$ of cadmium sulfate was injected intraperitoneally (ip) to pregnant JCL : ICR mice on the 7th day of gestation, $56 \%$ of live fetuses exhibited exencephaly and $24 \%$ of the conceptuses died. In the present experiment, using his findings as a base, the possible effect of cadmium pretreatment on teratogenicity and fetolethality was studied. Frequency change of exencephalic fetuses and of the fetal death rate was used as indicator.

\section{Materials and Methods}

Young adult JCL: ICR mice (Nippon CLEA Co., Ltd) were used. Nulliparous females were allowed to mate overnight with males of the same stock, and copulation was confirmed by the presence of a

* Present address : Department of Anatomy, Mie University School of Medicine, Tsu, Mie 514. 
vaginal plug the next morning. The day coitus was confirmed, was defined as day 0 of gestation. Throughout the experiment, mice were fed on a laboratory diet (NMF, Oriental Yeast Co., Ltd) and given tap water ad libitum. Pregnant fomales were divided into five groups (A-E). All the treatments were performed between 9:00 and 10:00 a. m. Twenty mice of Group A received no pretreatment and a $5 \mathrm{mg} /$ $\mathrm{kg}$ ip administration of cadmium sulfate on the $7 \mathrm{th}$ day of gestation. Nineteen mice of Group B received $0.5 \mathrm{mg} / \mathrm{kg}$ ip of cadmium sulfate on the 6 th day and $5 \mathrm{mg} / \mathrm{kg}$ ip on the 7 th day of gestation. Twenty mice of Group C were injected with $1 \mathrm{mg} / \mathrm{kg}$ subcutaneously (sc) on the 6 th day, and $5 \mathrm{mg} / \mathrm{kg}$ ip on the 7 th day. Twenty mice of Group $D$ received $1.0 \mathrm{mg} / \mathrm{kg}$ ip on the 6 th day and $5 \mathrm{mg} / \mathrm{kg}$ ip on the 7 th day. Twelve mice of Group E received $1.0 \mathrm{mg} / \mathrm{kg}$ ip on the 6 th day, but were not followed by treatment with a high dose of cadmium sulfate. All mice were killed by cervical dislocation on the 17 th day of gestation. The uterus was opened by longitudinal incision and the implantation site in the uterus and the condition (living, dead or resorbed) of each conceptus were noted. Surviving fetuses were examined for gross external malformations.

For statistical evaluation, the litter rather than the fetus is advocated as being the proper experimental unit upon which to base the statistical analysis in teratology experiments (Haseman, 1975). Thus, in this study, the malformation rate (number of exencephalic fetuses among total number of fetuses alive in utero) and fotal death rate (number of dead or resorbed fetuses per number of implantations) were calculated for each litter and the rates in each group were compared to those of other groups by means of Wilcoxon's rank sum test.

\section{Results}

The experiment showed that injection of cadmium sulfate did not affect the survival of dams. Exencephalic fetuses and dead fetuses were found frequently, just as in Yamamura's report (1972). The number of examined dams, the mean malformation ratio (each litter was averaged in each group) and the mean fetal death ratio (each litter averaged in each group) were summarized in Table 1. As for other external anomalies, one case of omphaloschisis was found in A, B, and D groups, respectively. Among them, the case in Group B was associated with exencephaly. One fetus of Group A showed craniorachischisis. Results of statistical analysis on the effect of pretreatment were summarized in Table 2. The total number of implantation sites in $A, B, C, D$ and $E$ groups were 252, 240, 244, 245, and 140, respectively. The live fetuses in each group totalled 198, 212, 221, 227, and 
Table 1. Decrease of malformation and fetal death by pretreatment with cadmium sulfate.

\begin{tabular}{ccccccc}
\hline Group & $\begin{array}{c}\text { Dose }(\mathrm{mg} / \mathrm{kg}) \\
\text { and route } \\
\text { of treatment }\end{array}$ & $\begin{array}{c}\text { Number of } \\
\text { dams }\end{array}$ & $\begin{array}{c}\text { Mean number } \\
\text { of nidations }\end{array}$ & $\begin{array}{c}\text { Mean malfor- } \\
\text { mation rate } \\
(\%)^{1}\end{array}$ & $\begin{array}{c}\text { Mean fetal } \\
\text { death rate } \\
(\%)^{2}\end{array}$ \\
\cline { 2 - 4 } day 6 & day 7 & & & & & \\
\hline A & 0 & 5 ip & 20 & 12.6 & 31.8 & 21.7 \\
B & 0.5 ip & 5 ip & 19 & 12.6 & 16.6 & 12.3 \\
C & 1 sc & 5 ip & 20 & 12.2 & 13.6 & 9.3 \\
D & 1 ip 5 ip & 20 & 12.3 & 6.7 & 7.2 \\
E & 1 ip & 0 & 12 & 11.7 & 0 & 8.3 \\
\hline
\end{tabular}

1 Number of exencephalic fetuses per total number of the fetuses alive in utero of each dam was averaged.

${ }^{2}$ Number of dead or resorbed fetuses per number of implants of each dam was averaged.

${ }^{3}$ intraperitoneal injection.

- subcutaneous injection.

Table 2. Results of statistical evaluation on the protective effect of pretreatment.

\begin{tabular}{|c|c|c|c|c|c|c|c|c|c|c|}
\hline \multirow{3}{*}{ Group } & \multirow{2}{*}{\multicolumn{2}{|c|}{$\begin{array}{l}\text { Dose }^{1} \text { and } \\
\text { route of } \\
\text { treatment }\end{array}$}} & \multicolumn{8}{|c|}{ Statistically significant level } \\
\hline & & & \multicolumn{4}{|c|}{ malformation ratio } & \multicolumn{4}{|c|}{ fetal death ratio } \\
\hline & day 6 & day 7 & $\mathbf{A}$ & $\mathrm{B}$ & $\mathrm{C}$ & D & A & B & $\mathrm{C}$ & $\mathrm{D}$ \\
\hline$A$ & 0 & $5 \mathrm{ip}^{2}$ & & & & & & & & \\
\hline B & 0.5 ip & 5 ip & - & & & & + & & & \\
\hline $\mathrm{C}$ & $1 \mathrm{sc}^{3}$ & 5 ip & + & - & & & 册 & - & & \\
\hline $\mathrm{D}$ & 1 ip & 5 ip & 册 & + & - & & 冊 & + & - & \\
\hline $\mathbf{E}$ & 1 ip & 0 & m & 冊 & $H$ & - & \# & - & - & - \\
\hline
\end{tabular}

$-: p>0.1,+:<0.1,+: p<0.05, \#: p<0.02$, Ht $: p<0.01$.

$1 \mathrm{mg} / \mathrm{kg}$

2 intraperitoneal in jection

${ }^{3}$ subcutaneous injection

128, and the overall number of exencephalic fetuses in each group was $57,34,30,11$ and 0 , respectively.

\section{Discussion}

In Group A, which received $5 \mathrm{mg} / \mathrm{kg}$ of cadmium sulfate ip on the 7th day of gestation, 57 among 198 live fetuses manifested exencephaly (28.8\%), and 54 fetuses among 252 conceptuses died (21.4\%). In Yamamura's report (1972), however, the frequencies attributable to the same dose in the same stock of mice were $58.5 \%$ and $26.6 \%$, respectively. The reason why the frequency of exencephalic fetus was lower 
in the present experiment is not clear. This result suggests that the teratogenicity and fetolethality of cadmium are easily influenced by some environmental conditions.

In Group E, which received $1 \mathrm{mg} / \mathrm{kg}$ ip on the $6 \mathrm{th}$ day, no malformed fetus was found among the 128 live fetuses. Thus the exencephalic fetuses found in other groups are attributable to the treatment on the 7th day rather than the preinjection on the 6th day of gestation. Fetal death rate in Group $\mathrm{E}$ was $8.6 \%$ (12 in 140), which is comparable to the figure reported in non-treated mice of the same stock $(9.2 \%$ in 41,533 term fetuses; Katsuya, 1975). Therefore, the pretreatment dose was considered to be subfetolethal.

There was no significant protective effect of the pretreatment at $0.5 \mathrm{mg} / \mathrm{kg}$ ip (Group B) against teratogenicity exerted by a high dose of the same compound. Subcutaneous preinjection of $1 \mathrm{mg} / \mathrm{kg}$ (Group C) was effective in terms of protection $(p<0.1)$, however the frequency of exencephaly was still higher than in Group $\mathrm{E}(\mathrm{p}<0.05)$. One mg/ $\mathrm{kg}$ ip (Group D) was highly effective $(p<0.01)$ and the malformation rate was lowered to a value comparable with Group E. However, in JCL : ICR mice, the spontaneous occurrence rate of exencephaly is approximately $0.08 \%$ (29 in 37,694 live fetuses; Katsuya, personal communication). Considering the above spontaneous occurrence rate, it cannot be concluded that the treatment of $1 \mathrm{mg} / \mathrm{kg}$ ip offers full protection against an increase of exencephaly. One $\mathrm{mg} / \mathrm{kg} \cdot \mathrm{ip}$ was more effective than $0.5 \mathrm{mg} / \mathrm{kg}$ ip $(\mathrm{p}<0.1)$.

In comparison with the protective effect against the teratogenicity, that against fetolethality was more pronounced. In Group B, C, and $D$, which received pretreatment, fetal death rates were significantly lower than in Group A ( $<<0.1, \mathrm{p}<0.02$, and $\mathrm{p}<0.01$, respectively), and were comparable to the rate in Group E.

In any case, the fact that even a very simple chemical compound induced tolerance against itself within 24 hours after a single injection of subteratogenic and subfetolethal dose, should be kept in mind in planning or evaluating teratological studies with repeated treatments.

A part of this study was presented in the 14th annual meeting of the Congenital Anomalies Research Association of Japan in 1974.

\begin{abstract}
Pretreatment with cadmium is reported to protect animals, to some extent, from acute toxicity of a following administration of a higher dose of cadmium itself. On the other hand, it is still unknown as to whether or not the teratogenicity and/or the fetolethality of cadmium are reduced by such pretreatment with cadmium. Based on
\end{abstract}


a report that administrations of cadmium sulfate to pregnant mice on their 7th day of gestation caused exencephaly and death of their fetuses, the authors investigated possible prevention of teratogenic and fetolethal effects of cadmium by pretreatment with a smaller dose of cadmium. On day 6 of gestation, a low dose $(0.5 \mathrm{mg} / \mathrm{kg}$ or $1 \mathrm{mg} / \mathrm{kg})$ of cadmium fulfate was administered intraperitoneally (ip) or subcutaneously (sc) to pregnant JCL:ICR mice, and on the next day a high dose $(5 \mathrm{mg} / \mathrm{kg})$ of the same compound was administered ip. Dams were sacrificed on day 17 of gestation and conceptuses were examined. A dose of $0.5 \mathrm{mg} / \mathrm{kg}$ of cadmium ip failed to show a protective effect against teratogenicity, but $1 \mathrm{mg} / \mathrm{kg}$ sc or $1 \mathrm{mg} / \mathrm{kg}$ ip was effective. However, induction of exencephaly was not completely blocked by these pretreatments. On the other hand, the protective effect against fetolethality was remarkable and fotal death rates were significantly lowered by overall pretreatment to control values.

\section{Reference}

Ferm, V.H. and Carpenter, S. J.: The relationship of cadmium and zinc in experimental mammalian teratogenesis. Lab. Invest., $18: 429-432,1968$.

Haseman, J.K. and Hogan, M.D.: Selection of the experimental unit in teratology studies. Teratology, $12: 165-172,1975$.

Ito, T. and Sawauchi, K.: Inhibitory effects on cadmium-induced testicular damage by pretreatment with smaller cardium dose. Okajimas Folia Anat. Jap., 42 : 107$117,1966$.

Katsuya, T.: Teratology control data: Review of Japanese publications. Teratology, 12: 200, 1975. (Abst.)

Parizek, J.: The destructive effect of cadmium ion on testicular tissue and its prevention by zinc. J. Endocrin., $15: 56-63,1957$.

Yamamura, H. : Effects of a cadmium salt on the development of mouse embryos. I. Appearance of exencephalia and anomalies of the axial skeleton. Acta Anat. Nipponica, $47: 263,1972$. (Abst. in Japanese).

Yoshikawa, H.: Preventive effect of pretreatment with low dose of metals on the acute toxicity of metals in mice. Industr. Health, $8: 184-191,1970$. 